\title{
The Right Honourable Beverley McLachlin
}

\section{Former Chief Justice of the Supreme Court of Canada}

Wrongful convictions occur in every country in the world. Canada, despite its claim to be a just society, is no exception.

For a very long time, people accepted wrongful convictions as an inevitable by-product of the criminal justice system. The solution, admittedly imperfect, was thought to lie in the common law principles of fair trial, cross-examination, burden of proof, and the requirement that guilt be proved beyond a reasonable doubt.

This has changed. We no longer accept the occasional wrongful conviction as inevitable. We know that every wrongful conviction represents a failure in our justice system. Such failures exact a huge price, both in terms of the suffering they impose on the person wrongfully convicted and families, and the disrepute they bring on the administration of justice.

And we no longer believe that the traditional common law and constitutional safeguards, vital as they remain, are sufficient by themselves to deal with the complex problem of wrongful convictions. With research, we have come to understand that despite differences in justice systems and domestic criminal laws, the causes of wrongful convictions are distressingly similar - tunnel vision, eyewitness misidentification, unreliable science, prosecutorial and police misconduct, false confession, reliance on disreputable witnesses and inadequate disclosure.

With this understanding of the complex causes of wrongful convictions, has come the conviction that we can and should do better. More research and deeper shared understandings of best practices are required if we are to diminish the number of wrongful convictions and make proper restitution when they occur. Prosecutors, defence lawyers, judges and justice officials find themselves dealing with the scourge of wrongful convictions on a daily basis; they desperately need access to research and thinking on the causes and consequences of wrongful convictions.

The Wrongful Conviction Law Review will provide this support, by creating a forum for the publication of research and insights into the causes of wrongful convictions and how to prevent them and deal with their aftermath when they occur. I believe this new publication will be a powerful tool in addressing the injustice of wrongful convictions and miscarriages of justice throughout the world. 